\title{
ASUHAN KEPERAWATAN PADA ANAK DENGAN DENGUE HEMMORHAGIC FEVER (DHF) : SEBUAH STUDY KASUS
}

\author{
Shinta Novebi Setyadevi, Rokhaidah \\ Fakultas Ilmu Kesehatan \\ Universitas Pembangunan Nasional Veteran Jakarta
}

\begin{abstract}
ABSTRAK
Demam berdarah dengue (DBD) adalah infeksi virus yang disebabkan oleh virus dengue, yang ditularkan melalui nyamuk aedes aegephty. Tujuan : studi ini adalah untuk menganalisis penerapan asuhan keperawatan pada anak dengan demam berdarah dengue meliputi pengkajian, diagnosa, intervensi, implementasi, dan evaluasi keperawatan. Metode : desain yang digunakan merupakan deskriptif dengan menggunakan metode studi kasus. Partisipasi yang digunakan adalah 1 pasien anak dengan diagnosis medik Demam Berdarah Dengue. Hasil : masalah keperawatan yang muncul pada kasus adalah defisiensi volume cairan berhubungan dengan kehilangan cairan melalui rute abnormal (peningkatan permeabilitas kapiler), hipertermi berhubungan dengan penyakit : infeksi virus Dengue, nyeri akut berhubungan dengan agens cedera biologis (pengeluaran histamin respon tubuh terhadap infeksi virus dengue), resiko perdarahan berhubungan dengan koagulopati inheren (kegagalan faktor bekuan). Setelah dilakukan tindakan keperawatan selama $3 \times 24$ jam hasil evaluasi semua diagnosis keperawatan teratasi sesuai dengan tujuan kriteria hasil yang ditetapkan. Kesimpulan : penerapan asuhan keperawatan pada anak dengan demam berdarah dengue mencapai hasil yang diharapkan karena adanya kerja sama yang baik antar perawat dan keluarga pasien dan juga dengan tim kesehatan yang lain.
\end{abstract}

Kata kunci: Anak, Asuhan Keperawatan, Demam Berdarah Dengue

\begin{abstract}
Dengue hemorrhagic fever (DHF) is a viral infection caused by dengue virus, which is transmitted through the Aedes aegephty mosquito. The purpose of this study was to analyze the application of nursing care to children with Dengue Hemorrhagic Fever to complete the assessment, diagnosis, intervention, implementation, and evaluation of nursing. Method, the design used is descriptive using case study methods. Participation used was 1 pediatric patient with a diagnosis of Dengue Hemorrhagic Fever. Results, Nursing problems that arise in the case are fluid volume deficiency associated with fluid loss through an abnormal route (Increased Capillary permeability), Hypertherm associated with disease: Dengue virus infection, Pain associated with biological agents,), Bleeding risk associated with Coagulopathy inherent (clot factor failure). After taking nursing actions for $3 \times 24$ hours the results of the evaluation of all nursing diagnoses are resolved in accordance with the objectives of the specified outcome criteria. In conclusion, the application of nursing care to children with dengue fever achieves the expected results due to good cooperation between nurses and patients' families and also with other health teams
\end{abstract}

Keywords: Children; Dengue hemorrhagic fever; Nursing Care

Alamat korespondensi: Kampus Fikes UPN Veteran Jakarta, Jalan Limo Raya Depok

Email: rokhaidah@upnvj.ac.id 


\section{PENDAHULUAN}

Dengue Fever (DF) merupakan infeksi virus yang disebabkan oleh nyamuk biasanya ditandai dengan gejala seperti onset mendadak demam tinggi $\left(39-40^{\circ} \mathrm{C}\right)$, nyeri retro-bulbar, nyeri otot, nyeri sendi, malaise, mual, ruam, limfadenopati dan trombositopenia. (Kumar, Singh, Tomar, dan Baijal, 2010). Dengue Haemorragic Fever (DHF) merupakan salah satu kategori penyakit kejadian luar biasa di Indonesia, Virus dengue sangat cocok hidup di iklim tropis atau pun sub tropis di berbagai belahan dunia, di mana mereka menyebabkan wabah musiman dengan berbagai variasi (Johansson, Dominici, dan Glass, 2009). Kasus cenderung meningkat pada musim penghujan (Desember Maret) dan menurun pada musim kemarau (Juni - September), walaupun setiap daerah mempunyai variasi musim sesuai regionalnya.

\section{METODE PENELITIAN}

Metode dalam penulisan karya tulis ilmiah yang digunakan penulis ini yaitu dengan metode deskriftif dan metode studi kepustakaan. Dalam metode deskriftif pendekatan yang digunakan adalah studi kasus menggunakan proses asuhan keperawatan dengan teknik dari pengumpulan data melalui :

a. Wawancara, tanya jawab dengan klien, keluarga dan perawat ruangan secara terarah dan sistematis.

b. Observasi, secara langsung dan pemeriksaan fisik kepada klien secara head to toe dan melakukan asuhan keperawatan secara langsung kepada klien.

c. Studi Dokumentasi, membaca catatan baik perawat atau tim kesehatan lain, serta melihat hasil laboratorium ataupun pemeriksaan penunjang klien dari buku status milik klien.

d. Studi Kepustakaan, mempelajari buku dan jurnal referensi untuk dijadikan sumber yang sesuai dengan masalah yang dialami sehingga dibandingkan antara teori dengan kasus.

\section{HASIL DAN PEMBAHASAN}

Pengkajian pada klien An.D didapatkan data subjektif dari perkataan klien maupun ibu klien yaitu Ibu klien mengatakan klien telah demam sejak 3 hari sebelum masuk rumah sakit, ibu klien mengatakan sebelumnya telah berobat dan meminum obat yang diresepkan oleh dokter namun tidak membaik, klien mengatakan lemas, klien mengatakan terasa dingin, klien mengatakan nyeri kepala saat beraktifitas dengan pengkajian nyeri $\mathrm{P}=$ klien mengatakan mulai merasakan nyeri pada hari sabtu ketika beraktivitas, $Q=$ klien mengatakan nyeri seperti di tekan, $\mathrm{R}=$ klien mengatakan nyeri disekitar kepala, $\mathrm{S}=$ klien mengatakan nyeri skala 4 dari $1-10$, $\mathrm{T}=$ klien mengatakan nyeri muncul secara mendadak pada hari sabtu saat beraktivitas, frekuensi sering, berkurang bila beristirahat, klien mengatakan merasakan pegal seluruh tubuh, klien mengatakan mual dirasakan saat makan ataupun setelah makan, klien mengatakan muntah 1x saat di IGD, klien mengatakan minum habis 1 3/4 botol $( \pm 1050 \mathrm{cc}$ ) sejak masuk ruang rawat, Ibu klien mengatakan klien jarang sekali minum dan sulit untuk disuruh minum, klien mengatakan telah BAK 9x $( \pm 2160$ cc) sejak masuk ruang rawat, Klien mengatakan belum BAB sejak kemarin, klien maupun ibu klien mengatakan belum pernah mengalami pengalaman penyakit DHF, Klien maupun ibu klien hanya mengetahui tanda gejala umum dari DHF, klien maupun ibu klien mengatakan belum mengetahui cara meminimalkan/ mencegah gejala yang memperparah kondisi.

Pengkajian pada klien An.D didapatkan Data objektif dari pengamatan adalah Pada kasus An.D saat pengkajian ditemukan data klien demam sudah 5 hari muncul secara mendadak suhu $38^{\circ} \mathrm{C}$, badan terasa dingin, lemas, nyeri kepala, pegal seluruh tubuh, mual, muntah, sulit minum, Capillary refill 3 detik, serta didapatkan hasil laboratorium trombosit $6710^{\wedge} 3 / \mathrm{ul}$ dan hematokrit $48 \%$. Manifestasi perdarahan sendiri ditemukan pada hari berikutnya yaitu berdarah mukosa bibir klien namun telah dihentikan, sedangkan manifestasi perdarahan lainnya tidak ditemukan seperti Uji tourniquet negatif, tidak ada petekie, tidak ada ekimosis, serta manifestasi perdarahan lainnya. Klien terlihat lemas, klien terlihat meringis menahan nyeri, klien terlihat memegang bagian kepala saat merasakan nyeri kepala, memiliki postur tubuh tidak siap karena lemas ataupun merasa nyeri 
kepala, klien terlihat memiliki kesadaran komposmentis dengan GCS 15, klien memiliki akral teraba hangat, klien memiliki turgor kulit kurang elastis, klien memiliki kulit lembab, klien terlihat bibir kering pecah pecah serta pucat pada bibir bagian dalam berwarna merah, klien terlihat pengisian kapiler 3 detik, klien terlihat terpasang infus pada ekstremitas sinistra atas dengan cairan Ringer Laktat $1728 \mathrm{cc} /$ hari, klien terlihat memiliki hasil TTV dengan TD $=90 / 70 \mathrm{mmHg}, \mathrm{S}=38,0^{\circ} \mathrm{C}, \mathrm{N}=$ $85 \mathrm{x} /$ menit, $\mathrm{RR}=21 \mathrm{x} /$ menit, Klien terlihat hasil lab tanggal 20 Februari 2019 terlampir dengan Trombosit $(\mathrm{Tr})=67.00010^{\wedge} 3 / \mathrm{ul}$, Hemoglobin $(\mathrm{Hb})=15,3 \mathrm{~g} / \mathrm{dl}$, Hematokrit $(\mathrm{Ht})=47 \%$, Leukosit $(\mathrm{L})=3.010^{\wedge} 3 / \mathrm{ul}$.

Diagnosis keperawatan yang ditemukan pada kasus adalah Defisiensi volume cairan berhubungan dengan kehilangan cairan melalui rute abnormal (Peningkatan permeabilitas Kapiler), Hipertermi berhubungan dengan penyakit : Infeksi virus Dengue, Nyeri akut berhubungan dengan agens cedera biologis (Pengeluaran histamin respon tubuh terhadap infeksi virus dengue), Resiko Perdarahan berhubungan dengan Koagulopati inheren (Kegagalan faktor bekuan).

Tindakan keperawatan yang telah dilakukan untuk mengatasi masalah keperawatan diantaranya adalah melakukan manajemen cairan berupa mempertahankan catatan intake dan output yang akurat, memonitor status hidrasi (kelembaban membran mukosa, nadi adekuat, tekanan darah ortostatik), memonitor vital sign, kolaborasikan pemberian cairan, mendorong pasien untuk menambah intake oral. Monitor suhu sesering mungkin, memonitor Insisible Water Lose, memonitor warna dan suhu kulit, melakukan kompres hangat, kolaborasi pemberian antiperitik, melakukan pengkajian nyeri secara komprehensif termasuk lokasi, karakteristik, durasi frekuensi, kualitas dan faktor presipitasi, mengobservasi reaksi nonverbal dan ketidaknyamanan, Memonitor ketat tanda-tanda perdarahan, memonitor nilai laboratorium (koagulasi)

Demam berdarah dengue adalah penyakit yang disebabkan oleh virus dengue yang ditularkan melalui gigitan nyamuk Aedes Aegytpti, Virus yang telah berviremia dalam tubuh manusia akan menimbulkan beberapa menurut penelitian (Khadijah \& Utama, 2017) manifestasi klinis yang muncul secara mendadak diawali dengan demam, sakit kepala yang berat, nyeri retroorbital, nyeri otot (myalgia) dan nyeri sendi (atralgia) yang sangat menyakitkan, ruam kulit (rash), tanda perdarahan (Tes tourniquet positif, petekie, ekimosis, purpura, perdarahan mukosa, saluran gastrointestinal, tempat suntikan atau lokasi lain, hematemesis, melena), nyeri perut, mual, nafsu makan serta minum menurun, terdapat tanda kegagalan sirkulasi seperti Capillary refill $>2$ detik, Pada pemeriksaan darah terjadi trombositopeni (normal : 150.000-300.000 10^3/ul), leukopenia (normal 4.5 - $13.010^{\wedge} 3 / \mathrm{ul}$ ), dan terjadi hemokonsentrasi (normal 33 - $45 \%$ ). Pemeriksaan penunjang Menurut WHO (2009) terdapat beberapa pemeriksaan seperti pemeriksaan darah lengkap, Pemeriksaan tes tourniquet dengan hasil positif $>20$. Menurut Megariani, Mariko, Alkamar, dan Putra (2014) pemeriksaan NS1 positif. Menurut Rini dan Aryanti (2010) pemeriksaan serologis berupa IgM dan IgG untuk memberdakan infeksi primer atau sekunder. Menurut Tendean (2009) Pemeriksaan radiologi dan USG untuk melihat kelainan yang terdeteksi seperti hepatomegali, efusi pleura, dan cairan dalam rongga peritoneum (asites). Pada kasus ini telah dilakukan pemeriksaan laboratorium darah lengkap dengan hasil rombosit 67.000 10^3/ul (menurun), leukosit 3.0 10^3/ul (menurun), dan hematokrit 48\% (meningkat 3\%).

Asuhan keperawatan dilakukan secara teliti untuk mencapai tujuan yang diharapkan berdasarkan dengan kriteria hasil yang di tentukan, melalui proses yang diawali dengan pengkajian yang dilakukan pada kasus ini didapatkan melalui pemeriksaan fisik, dan data - data yang diperoleh dengan cara observasi maupun wawancara terhadap klien yang dibantu oleh Ibu klien. Pengkajian pada klien An.D didapati kesenjangan manifestasi klinis antara kasus dan teori. Pada kasus tidak ditemukan ptekie, ekimosis, uji tourniquet positif, hanya terdapat perdarahan minor yaitu berdarahnya mukosa bibir yang dapat teratasi dengan cepat.

Diagnosis keperawatan merupakan hasil data yang telah dikelompokan, diidentifikasi masalah, penyebab, dan kemampuan klien untuk dapat mencegah atau memecahkan masalah (Budiono, 2016). Diagnosis keperawatan yang terdapat pada kasus adalah 4 diagnosis actual dan 2 diagnosis risiko. Setelah mengidentifikasi Diagnosis keperawatan, tahap berikutnya adalah 
perencanaan. Menurut Budiono (2016) perencanaan keperawatan adalah pembentukan strategi tindakan keperawatan dan mengatasi masalah-masalah yang telah diidentifikasi dalam diagnosis keperawatan secara efektif dan efisien.

Pada tahap perencanaan menentukan prioritas masalah, tujuan, kriteria hasil penulis menemukan beberapa hambatan karena dalam menyusun rencana keperawatan penulis mengacu pada pedoman keperawatan NANDA (2018) NOC - NIC (2016). Perencanaan keperawatan dalam kenyataannya diperlukan penyesuaian dengan kondisi klien saat itu, sedangkan faktor yang mendukung dalam menerapkan perencanaan meliputi adanya keluarga klien, klien, dan perawat ruangan yang kooperatif.

Komplikasi DBD menurut Soedarto (2012) dapat berupa Syok hypovolemia terjadi bila kebocoran plasma dalam jumlah lebih dari 30\% volume darah dan terjadi efusi pleura karena terjadinya kegagalan sirkulasi. Kejang yang memiliki 2 kemungkinan yaitu demam yang terlalu tinggi ataupun kebocoran plasma (kekurangan cairan berlebih). Menurut leovani, Sembiring, dan Winarto (2015) komplikasi yang muncul pada orang dengan terjangkit virus dengue yaitu kelainan hati ditandai dengan ditemukannya peningkatan enzim hati (SGOT/SGPT), gagal ginjal akut umumnya terjadi pada fase terminal akibat shock yang tidak teratasi dengan baik yang ditandai dengan penurunan jumlah urin dan peningkatan kadar ureum maupun kratinin. Ensefelopati ditemukan biasanya dengan kriteria kesadaran pasien menurun yaitu somnolen, gastric bleeding $(+)$, akral dingin, tekanan darah hipotensi sampai dengan tidak terukur, nadi teraba cepat dan lemah, pernafasan sesak dan apnea, serta disertai dengan peningkatan kadar SGOT/SGPT. Pada kasus ini tidak ditemukan tanda - tanda komplikasi karena dilakukan penanganan yang tepat.

Evaluasi adalah tahap terakhir dari proses asuhan keperawatan. Hasil evaluasi kasus setelah dilakukan tindakan keperawatan sesuai dengan diagnosis keperawatan dan tujuan yang telah di tetapkan selama 3 × 24 jam, didapatkan hasil bahwa semua masalah teratasi dengan tujuan tercapai pada hari ketiga.

\section{SIMPULAN}

Asuhan Keperawatan pada Anak dengan Diagnosa medis Dengue Haemorrhagic Fever pada study kasus ini dilaksankan selama 3 hari, asuhan keperawatan dimulai dari pengkajian dan pemeriksan fisik, kemudian dilanjutkan dengan penentuan diagnosis medis, penyusunan intervensi, implementasi dan evaluasi. Hasil analisis data ditemukan 5 diagnosis keperawatan yang berhasil diatasi dengan pencapaian kriteria hasil sesuai dengan tujuan yang ditetapkan. Selama implementasi penulis telah menerapkan prinsip family centre care dengan melibatkan ibu dalam pemberian asuhan keperawatan. Prinsip atraumatic care dilaksanakan untuk meminimalisasi trauma anak akibat hospitalisasi.

\section{SARAN}

Pemberian asuhan keperawatan pada anak yang menderita demam berdarah dengue dapat dilakukan dengan menerapkan prinsip family center care yaitu melibatkan peran keluarga dalam perawatan anak dan menerapkan prinsip atraumatic care sehingga asuhan keperawatan dapat berjalan secara efektif.

\section{DAFTAR PUSTAKA}

Kumar, K., Singh, P. K., Tomar, J., \& Baijal, S. (2010). Dengue: epidemiology, prevention and pressing need for vaccine development. Asian Pacific Journal of Tropical Medicine, vol 3 No 12, Desember 2010.

Kementerian Kesehatan RI. (2018). Sekretariat Jenderal Profil Kesehatan Indonesia Tahun 2017. Jakarta : Kementerian Kesehatan RI.

Johansson, M. A., Dominici, F., \& Glass, G. E. (2009). Local and Global Effects of Climate on Dengue Transmission in Puerto Rico. PLoS Neglected Tropical Diseases, Vol 3 No. 2 
Candra, A. (2010). Demam Berdarah Dengue: Epidemiologi, Patogenesis, dan Faktor Risiko Penularan. Aspirator, Vol. 2 No. 2, Tahun 2010.

Leovani, V.,Sembiring, LP., \& Winarto. (2015). Gambaran klinis dan komplikasi pasien demam berdarah dengue derajat iii dan iv di bagian penyakit dalam rsud arifin achmad provinsi riau periode 1 januari 2012 -31 desember 2013. Jurnal Online Mahasiswa Fakultas Kedokteran, Volume 2 No. 2, Oktober 2015.

WHO. (2009). Dengue guidelines for diagnosis, treatment, prevention and control New edition 2009. France : WHO Library Cataloguing-in-Publication Data.

Dinas Kesehatan Kota Depok. (2018). Profil Dinas Kesehatan Kota Depok 2017. Depok : Dinas Kesehatan Kota Depok.

Pangaribuan, A., Prawirohartono, EP., \& Laksanawati, IS. (2014). Faktor Prognosis Kematian Sindrom Syok Dengue. Jurnal Sari Pediatri, Vol. 15 No. 5, Februari 2014.

Khadijah, A.N., Utama, I.M.G.D.L. (2017). Gambaran Gejala Klinis Demam Berdarah Dengue pada Anak di RSUP Sanglah, Denpasar Selama Bulan Januari-Desember 2013. E-Jurnal Medika Udayana, Vol 6 No.11, November 2017.

Soedarto. (2012) .Demam Berdarah Dengue Dengue Haemorragic Fever. Jakarta : CV Sagung Seto.

Megariani, Mariko, R., Alkamar, A., \& Putra, AE. (2014). Uji Diagnostik Pemeriksaan Antigen Nonstruktural 1 untuk Deteksi Dini Infeksi Virus Dengue pada Anak. Sari Pediatri, Vol. 16, No. 2, Agustus 2014. Diakses pada tanggal 21 Maret 2019.

Rini, D.P \& Aryati. (2010). Sd dengue duo® (ns1, igg, igm) rapid test dalam menunjang diagnosis infeksi virus dengue. Indonesian Journal of Clinical Pathology and Medical Laboratory, Vol 16 No 2, Maret 2010.

Tandean, M., (2009). Masalah Dengue di Indonesia. Jurnal Kedokteran Meditek, Vol 16 No 42, September-Desember 2009. Diakses pada tanggal 24 Maret 2019.

Budiono. (2016). Konsep Dasar Keperawatan, Modul Bahan Ajar Cetak Keperawatan. Jakarta : Pusdik SDM. 